\title{
A CASE OF GAUCHER'S DISEASE WITH BIOPSY OF THE TYPICAL PINGUECULAE
}

BY

\author{
TERENCE EAST and L. H. SAVIN
}

LONDON

OF recent years eye signs have been described in most of the lipoidoses. In Gaucher's disease according to McNee (1937) "the eyes show a phenomenon which is so constant as to be almost pathognomonic:- a brownish-yellow wedge-shaped thickening or pinguecula appears first on the nasal and then on the temporal side of each eye."

The disease is sufficiently rare to justify the clinical and histological description of such a case. The first description by Gaucher (1882) was of an apparently idiopathic enlargement of the spleen of a girl who had undergone severe privations during the siege of Paris. He noted that the skin was slightly jaundiced, and the conjunctivae yellowish towards the inner angle of the eyes. Sections of the spleen showed large cells, staining with difficulty. In the light of the pathological knowledge of the time the most likely diagnosis seemed to be primary epithelioma of the spleen.

Subsequent descriptions have slightly clarified the clinical picture. Gaucher's splenomegaly is often a familial disease, more common in females than in males. Jews are especially susceptible. Splenomegaly is associated with anaemia and a haemorrhagic tendency (Ellis, 1938). The skin is yellowish-brown, with often a leaden pigmentation on head, neck, hands, and legs. A malar flush is common. Myopia is found in many cases (Bloom, Groen, Portna, 1936). The liver may be enlarged also. The lower end of the femur may show a bottle-shaped enlargement.

The disease often lasts many years with comparatively little general disturbance. Death eventually takes place from inanition, haemorrhage, and intercurrent infections. There may be terminal mental defect.

Post-mortem the spleen is much enlarged. The cut surface shows greyish-white or yellow from masses of Gaucher cells. These are not epitheliomatous, as Gaucher thought, but are lipoid storage cells of the reticulo-endothelial system. They are $20-80 \mu$ across, with many small, pyknotic, eccentric nuclei. They stain badly with the fat-staining dyes, and are packed with a cerebrosidekerasin-soluble in alcohol but not in ether. Kerasin is rather an inert substance chemically. On acid hydrolysis it splits up into d.galactose, lignoceric acid, and sphingosine, a base with a complicated molecule said to contain 18 carbon atoms. 
The spleen may also show "cavernous foci, fibrous nodules, small infarcts. The liver is less enlarged in proportion, often cirrhotic, showing Gaucher cells. The lymph glands though not grossly enlarged may be involved. The long bones, vertebrae, and skull contain numerous Gaucher cells. Haemorrhages may be found in the internal organs.

In our own case the details were as follows:-The patient was a telegraph maintenance officer, aged 59 years, who complained of fatigue, quite noticeable towards evening, so that he had no energy to do anything. This lassitude had come on after a prolonged attack of influenza six months previously. Since a heavy cold a month ago he had noticed breathlessness on going upstairs. His mouth had been rather sore for a month.

His past history was free from disease except for malaria and typhoid fever many years ago.

There was nothing of note in the family history.

He was a thin man, with rather a dusky complexion. There were faint irregular areas of brownish pigmentation on the face, especially on the cheeks and forehead. The backs of the hands were unusually brownish. Telangiectatic venules were conspicuous on the nose and cheeks. The eyeballs were yellowish. On either side of the cornea in each eye were pingueculae, triangular in shape, rather granular in appearance and of a brownish-yellow colour. They were more raised and brown and larger than the pingueculae often seen on the eyeballs of elderly people. The illustration gives a good idea of the appearance of this patient's eyes. He was emmetropic.

The abdomen was thin, and the huge spleen was easily seen and felt. It was hard and smooth and not tender. $\mathrm{He}$ was quite unaware of the splenic tumour and had suffered no discomfort in that region. The liver was slightly enlarged and very firm, with a blunt edge and smooth surface. There was no ascites; no glands were enlarged. ' On the lower part of the left leg just above the ankle was a purplish brown pigmented area, resembling that seen in cases of old varicose ulceration. The surface of the skin was dry and scaly. There had been no spontaneous haemorrhages into the skin or mucous membranes, such as sometimes occur in Gaucher's disease. The other organs were normal.

\section{Investigations}

There was some degree of anaemia, which was no doubt responsible for his symptoms. The red cells were 3.22 million per c.mm. The haemoglobin was only 64 per cent., so the colour index was 1.03. The leucocytes were 5,400 per c.mm., not reaching the degree of leucopenia of some cases. The differential count was normal. There was slight variation in size and shape of the red cells, with occasional nucleated cells. The reticulocytes were $3 \cdot 7$ 
Pingueculae in Gaucher's disease. Note, that the brownish-yellow pigmentation is not appreciable in the reproduction in monochrome. 
per cent. The platelets were not diminished as is sometimes the case. The Wassermann reaction was negative. The blood cholesterol was normal, as is usual in this disease. The fragility of the red cells showed a very slight increase to subnormal solutions of saline (Dr. Dacie).

The liver defect, presumably lipoid infiltration, was no doubt responsible for the raised bilirubin in the blood, for the van den Bergh reaction gave 1.5 units of haemobilirubin. The presence of bile salts in the urine would be due to the same cause. The tolerance to laevulose was normal.

Skiagrams of the long bones showed no enlargement or rarefaction due to lipoid deposits.

Biopsy of the pingueculae was done by one of us (L.H.S.). We are indebted to Dr. H. A. Lucas for a report on the microscopical sections. "Situated beneath the epithelium are small collections of large endothelial cells. The cytoplasm of these cells is degenerate and shows a foamy appearance. The frozen sections show no fatstaining particles. The absence of fat-staining and the foamy appearance of the cells is similar to that observed in the endothelial cells of the spleen in cases of Gaucher's disease. The small amount of tissue available made further investigation impossible. The histological findings are compatible with Gaucher's disease."

Dr. Grey kindly attempted to analyse a fragment for kerasin, but it was too small for him to get any result.

\section{Comment}

The case presents the features of Gaucher's disease, with involvement of the liver, and the usual slight anaemia, and typical pingueculae. The microscopical findings of the biopsy of the pingueculae are of interest, and we have not been able to find histological records of other cases. These lipoid deposits on the eyeball are so peculiar and striking that it seems worth while to draw attention to them.

\section{REFERENCES}

Bloom, T. F., Groen, J., Portna, C. (1936).-Quart. Jl.Med., Vol. V, pp. 517 528.

Ellis, R. W. B. (1938).-British Encyclopaedia of Medical Practice, Vol. VIII, pp. 67-79,

GAUCheR, P. C. E. (1882).-De l'épithélioma primitif de la rate-hypertrophie idiopathique de la rate sans leucémie (Octave Doin, Paris).

MCNEE, J. W. (1937). - Textbook of the Practice of Medicine. Edited by F. W. Price, p. 841 . 